\title{
STRATEGI PEMENUHAN KEBUTUHAN INDUSTRI PENGOLAHAN IKAN DI PELABUHAN PERIKANAN SAMUDERA BELAWAN
}

\section{STRATEGY TO SUPPLY THE NEED OF FISH PROCESSING INDUSTRY IN OCEAN FISHING PORT OF BELAWAN}

\author{
Muhammad Reza ${ }^{1}$, Tri Wiji Nurani ${ }^{2}$, Iin Solihin ${ }^{2}$ \\ ${ }^{1}$ Program Studi Teknologi Perikanan Laut, Sekolah Pascasarjana \\ ${ }^{2}$ Departemen Pemanfaatan Sumberdaya Perikanan, \\ Fakultas Perikanan dan Ilmu Kelautan, Institut Pertanian Bogor \\ Korespondensi: reza_muhammad@apps.ipb.ac.id
}

\begin{abstract}
The ocean fishing port of Belawan is the development center of the fish processing industry and fishing center in the North Sumatra Province. There were 25 fish processing industries in the Ocean fishing port of Belawan. The need for raw material of the fish processing industry increase per year, but the need is not fulfilled by the continuity supply. The objectives of this study were to estimate the needs of raw materials for the fish processing industry, to identify the origin of raw materials for fish processing industry and estimate the availability of raw materials, to formulize strategies for the fulfillment of raw materials of the fish processing industry. The collecting data method used were observation and interview method. Then, the data analysis used was descriptive and SWOT analysis. The result showed that the needs of raw materials for fish processing industry was 85.714 ton/year. While, the fish origin in the ocean fishing port of Belawan were from fish landed inside the fishing port and outside fishing port (Aceh, Bengkulu, Padang, Batubara, and Tanjung Balai). Then, the supply estimation (operational capacity) was 54.429 tons/year. The level of need supplying of fish processing industry was $63 \%$. Based on the SWOT analysis, the strategies to supply the need of fish processing industry were developing the port facilities (cold storage) and utilization of human resources, making collaboration with related stakeholder to support the supply and price of raw material in stable condition, conducting law enforcement through individual that obstruct the raw material to industry.
\end{abstract}

Keywords: need estimation, strategy, supply estimation, supply level

\begin{abstract}
ABSTRAK
Pelabuhan Perikanan Samudera (PPS) Belawan merupakan lokasi pusat pengembangan industri pengolahan ikan dan pusat penangkapan ikan di Provinsi Sumatera Utara. PPS Belawan terdapat sekitar 25 industri pengolahan ikan yang ada disana. Kebutuhan bahan baku industri pengolahan ikan terus meningkat per tahunnya, tetapi kebutuhan tersebut tidak terpenuhi sepenuhnya oleh bahan baku yang ada. Tujuan dari penelitian ini adalah untuk mengestimasi kebutuhan bahan baku untuk industri pengolahan ikan, mengidentifikasi asal ikan dan mengestimasi persediaan ikan di PPS Belawan, dan merumuskan strategi tentang pemenuhan bahan baku industri pengolahan ikan. Metode pengumpulan data yang digunakan adalah metode observasi dan wawancara. Kemudian, analisis data yang digunakan adalah analisis deskriptif dan analisis SWOT. Hasil penelitian menunjukkan bahwa kebutuhan bahan baku untuk industri pengolahan ikan adalah 85.714 ton/tahun. Sementara itu, asal ikan di pelabuhan perikanan samudera Belawan berasal dari ikan yang di daratkan pelabuhan perikanan samudera belawan dan dari luar pelabuhan perikanan samudera belawan (Aceh, Bengkulu, Padang, Batubara, dan Tanjung Balai). Kemudian, kapasitas operasional industri pengolahan ikan sebesar 54.429 ton. Tingkat pemenuhan kebutuhan industri pengolahan ikan adalah 63\%. Berdasarkan analisis SWOT, strategi dalam pemenuhan bahan baku tersebut adalah melakukan pengembangan fasilitas (cold storage dan aksesibilitas tansportasi) serta pemanfaatan SDM untuk memenuhi kebutuhan indutri pengolahan, melakukan kerjasama dengan pihak luar dalam dalam menunjang ketersediaan dan harga bahan baku yang terus stabil, mendorong armada melakukan penangkapan ikan yang menjadi kebutuhan industri pengolahan ikan, dan melakukan penegakan hukum terhadap yang menghambat akses bahan baku masuk ke industri.
\end{abstract}

Kata kunci: kebutuhan bahan baku, pasokan bahan baku, strategi, tingkat pemenuhan 


\section{PENDAHULUAN}

Pelabuhan Perikanan Samudera (PPS) Belawan terletak pada posisi yang cukup strategis, yaitu di antara perairan pantai Timur Sumatera dan Selat Malaka (WPP RI 571), juga berada di perairan Zona Ekonomi Ekslusif Indonesia (ZEEI), yang merupakan pintu masuk bagi kegiatan ekonomi di beberapa negara di Asia (Siahaan et al. 2016). PPS Belawan merupakan lokasi konsentrasi pengembangan industri pengolahan ikan dan sentra produksi penangkapan serta merupakan fokus pembangunan yang terdapat pada masterplan perluasan dan percepatan pembangunan ekonomi Indonesia (Solihin et al. 2012).

Industri pengolahan ikan yang berada di PPS Belawan sebanyak 25 industri pengolahan ikan (PPS Belawan 2017). Jenis olahan ikan yang dihasilkan oleh unit pengolahan ikan didominasi oleh produk ikan beku dengan jumlah produksi sebesar 7.756 ton/tahun (Solihin et al. 2012). Pada tahun 2012 kebutuhan bahan baku untuk industri pengolahan sebesar 52.552 ton (Solihin et al. 2012). Kebutuhan tersebut dipenuhi oleh produksi ikan PPS Belawan sebesar 63.305 ton (PPS Belawan 2017). Namun, pada tahun 2015 total kapasitas industri pengolahan meningkat menjadi 78.570 ton (Nurul 2015). Kapasitas tersebut hanya dipenuhi oleh PPS Belawan sebesar $59 \%$ yaitu 46.628 ton (PPS Belawan 2017). Dengan demikian, terdapat kesenjangan antara kapasitas terpasang industri pengolahan dengan produksi ikan PPS Belawan. Hal tersebut diduga akibat adanya penurunan produksi ikan sebesar 13,72\% per tahun dari rentang waktu 2012-2017 (PPS Belawan 2017).

PPS Belawan yang telah ditetapkan menjadi lokasi konsentrasi pengembangan industri pengolahan ikan, akan mengalami kendala dengan penurunan produksi ikan di pelabuhan tersebut. Penurunan produksi tiap tahunnya dikhawatirkan tidak dapat memenuhi kebutuhan bahan baku yang mungkin selalu meningkat setiap tahunnya (Purwaningsih dan Partiwi 2014). Kondisi tersebut akan menyebabkan fungsi pelabuhan perikanan sebagai fasilitator penyediaan bahan baku ikan tidak dapat dipenuhi oleh PPS Belawan (Permen KP No 8 Tahun 2012). Untuk itu, PPS Belawan perlu mengetahui seberapa besar kebutuhan industri pengolahan ikan dan persediaan ikan di PPS Belawan.

Penelitian ini bertujuan untuk mengestimasi jumlah kebutuhan bahan baku industri pengolahan ikan di PPS Belawan, mengidentifikasi asal bahan baku dan estimasi ketersediaan bahan baku di PPS Belawan, dan merumuskan strategi pemenuhan kebutuhan industri pengolahan ikan di PPS Belawan.

\section{METODE PENELITIAN}

\section{Waktu dan tempat penelitian}

Pengumpulan data estimasi
kebutuhan dan estimasi persediaan
dilakukan di industri pengolahan ikan dan
kapal-kapal di PPS Belawan. Pengumpulan
data untuk analisis SWOT dilakukan di
kantor PPS Belawan. Pengumpulan data
dilakukan pada bulan September-Oktober
2019.

\section{Pengumpulan data}

Pengumpulan data penelitian ini memerlukan sampel yang berkaitan dengan informasi yang dibutuhkan. Sampel yang digunakan terdiri dari armada penangkapan, pengelola PPS Belawan, dan industri pengolahan ikan di PPS Belawan. Penentuan sampel ditentukan berdasarkan panduan FAO (2017), yaitu 25\% dari populasi. Sampel industri pengolahan ikan diambil sebanyak 7 unit $(n=25)$, sampel armada penangkapan diambil sebanyak 60 unit armada purse seine $(n=241)$, dan sampel pengelola PPS Belawan diwakilkan oleh beberapa ahli yang memiliki jabatan dan kedudukan di PPS Belawan. Jenis dan sumber data yang dikumpulkan dalam penelitian ini (Tabel 1).

\section{Analisis data}

Data estimasi kebutuhan industri pengolahan ikan di PPS Belawan dianalisis menggunakan analisis estimasi kebutuhan sebagai berikut:

$$
E K T=\sum_{n=1}^{i} K_{i}
$$

Keterangan:

$E K T=$ Estimasi kapasitas total terpasang (ton)

$K i=$ Kapasitas terpasang dari satu industri pengolahan ikan (ton) 
Identifikasi asal ikan dianalisis secara dekriptif, sedangkan estimasi persediaan ikan dianalisis dengan analisis persediaan ikan berikut ini rumus yang digunakan:

$$
\begin{aligned}
& J P=\frac{\sum P_{n}}{n} \times N \\
& J L=K O \times L
\end{aligned}
$$

Keterangan:

$J P=$ Jumlah ikan yang di daratkan di PPS Belawan (ton)

$J L=$ Jumlah ikan dari luar yang di datangkan ke PPS Belawan (ton)

$n=$ Jumlah sampel kapal (unit)

$N=$ Jumlah populasi kapal (unit)

$P=$ Jumlah produksi per kapal (ton)

$K O=$ Kapasitas operasional (ton)

$L=$ Jumlah ikan dari luar (\%)

Strategi pemenuhan kebutuhan industri pengolahan ikan

Strategi pemenuhan kebutuhan industri pengolahan ikan dianalisis dengan analisis SWOT. Analisis ini didasarkan dengan memaksimalkan kekuatan (strength) dan peluang (opportunities), namun secara bersamaan dapat meminimalkan kelemahan (weakness) dan ancaman (threats). Langkah-langkah yang dilakukan dalam analisis SWOT dapat dilihat pada Gambar 1 (Rangkuti 2006).

Sebelum membuat strategi maka dalam pembuatan SWOT perlu membuat matriks internal eksternal yang dibagi menjadi 9 kuadran. Matriks internal eksternal didasarkan pada dua dimensi kunci yaitu sumbu $\mathrm{x}$ yang mempresentasikan skor bobot IFAS dan sumbu y mempresentasikan skor bobot EFAS (Gambar 2).

Strategi yang dihasilkan yaitu: strategi (S-O) menggunakan unsur kekuatan untuk memanfaatkan peluang; strategi (S-T) menggunakan unsur kekuatan untuk menghadapi ancaman; strategi (W-O) memanfaatkan peluang untuk meminimalkan unsur kelemahan dan strategi (W-T) meminimalkan unsur kelemahan dan menghindari ancaman (Rangkuti 2006).

\begin{tabular}{|c|c|c|c|c|c|}
\hline No & Tujuan & Data & $\begin{array}{c}\text { Pengumpulan } \\
\text { data }\end{array}$ & Sumber data & $\begin{array}{c}\text { Analisis } \\
\text { data }\end{array}$ \\
\hline 1. & $\begin{array}{l}\text { Mengestimasi kebu- } \\
\text { tuhan bahan baku } \\
\text { industri pengolahan } \\
\text { ikan di PPS Belawan }\end{array}$ & $\begin{array}{c}\text { Kapasitas } \\
\text { terpasang } \\
\text { industri (ton) }\end{array}$ & $\begin{array}{c}\text { Obeservasi } \\
\text { dan } \\
\text { wawancara }\end{array}$ & $\begin{array}{c}\text { Industri } \\
\text { pengolahan } \\
\text { ikan }\end{array}$ & $\begin{array}{c}\text { Analisis } \\
\text { estimasi } \\
\text { kebutuhan } \\
\text { bahan baku }\end{array}$ \\
\hline 2. & $\begin{array}{l}\text { Mengidentifikasi asal } \\
\text { ikan dan estimasi } \\
\text { persediaan ikan di } \\
\text { PPS Belawan }\end{array}$ & $\begin{array}{c}\text { Daerah asal } \\
\text { ikan, jumlah } \\
\text { ikan dari luar } \\
\text { (ton), Jumlah } \\
\text { kapal, jumlah } \\
\text { produksi per } \\
\text { kapal (ton), } \\
\text { dan kapasitas } \\
\text { operasional } \\
\text { (ton) }\end{array}$ & $\begin{array}{l}\text { Obeservasi } \\
\text { dan } \\
\text { wawancara }\end{array}$ & $\begin{array}{c}\text { Industri } \\
\text { pengolahan } \\
\text { ikan dan } \\
\text { armada } \\
\text { penangkapan } \\
\text { ikan }\end{array}$ & $\begin{array}{c}\text { Analisis } \\
\text { deskriptif } \\
\text { dan analisis } \\
\text { estimasi } \\
\text { persediaan } \\
\text { ikan }\end{array}$ \\
\hline 3. & $\begin{array}{l}\text { Merumuskan strategi } \\
\text { pemenuhan kebutu- } \\
\text { han industri pengola- } \\
\text { han ikan }\end{array}$ & $\begin{array}{l}\text { Kekuatan, } \\
\text { kelemahan, } \\
\text { peluang dan } \\
\text { ancaman }\end{array}$ & $\begin{array}{l}\text { Obeservasi } \\
\text { dan } \\
\text { wawancara }\end{array}$ & $\begin{array}{c}\text { Pengelola } \\
\text { PPS Belawan }\end{array}$ & $\begin{array}{l}\text { Analisis } \\
\text { SWOT }\end{array}$ \\
\hline
\end{tabular}

Tabel 1. Jenis dan sumber data 


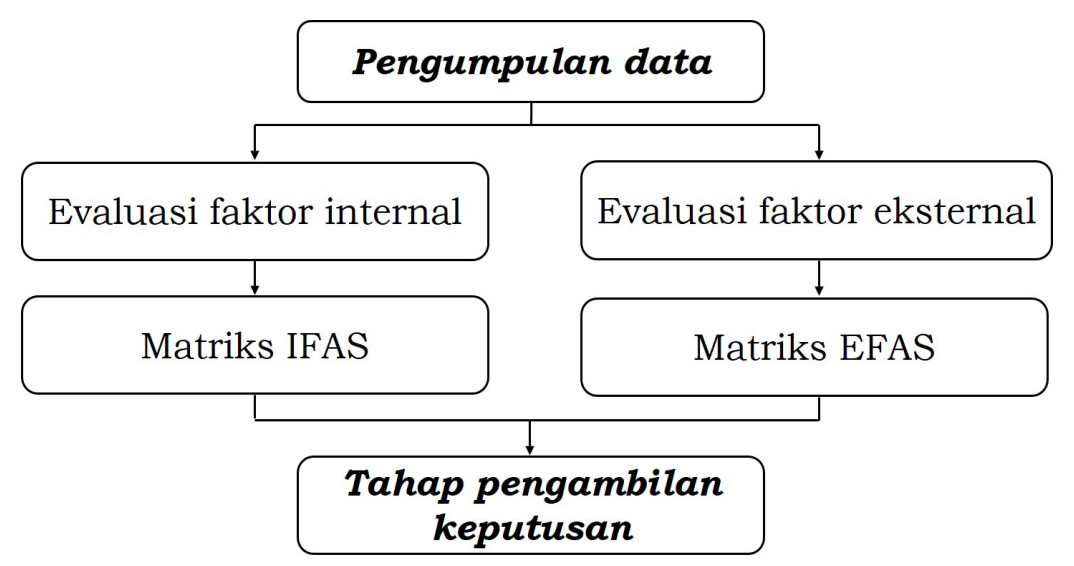

Gambar 1. Diagram alir analisis SWOT

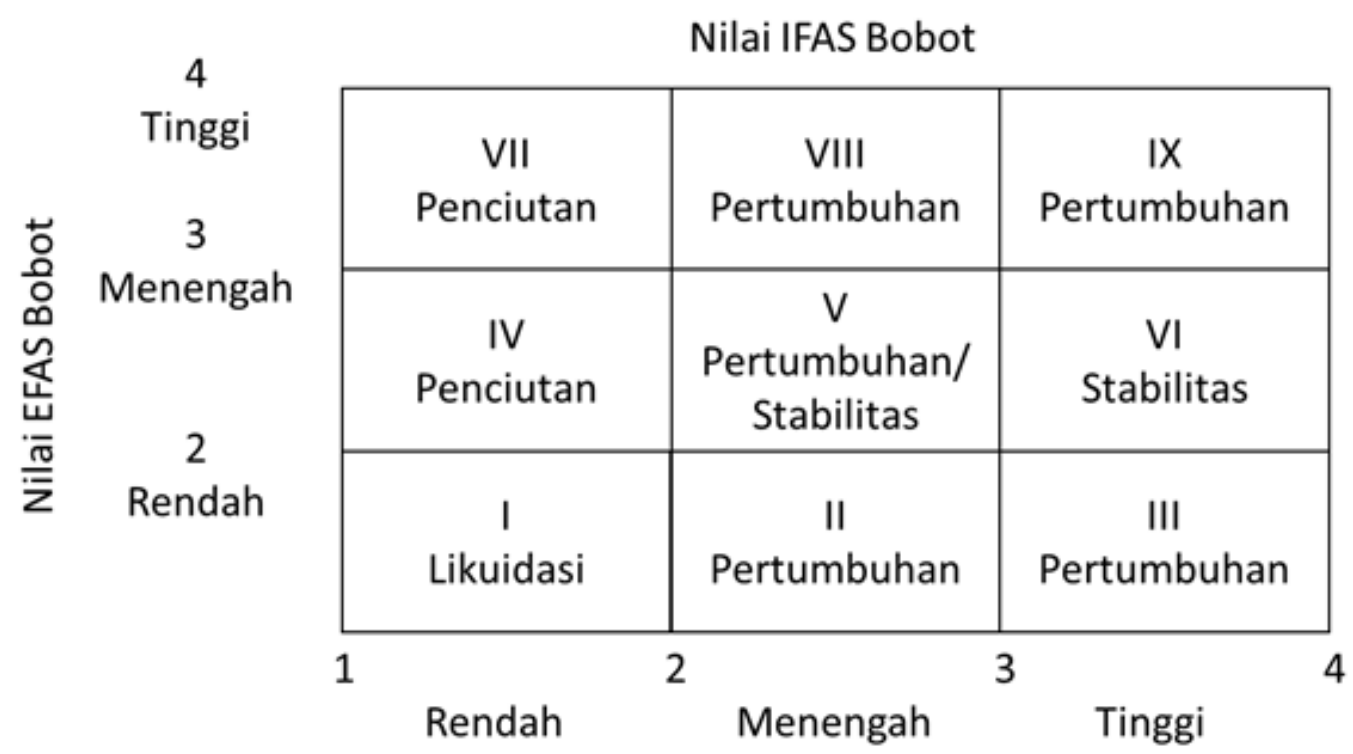

Gambar 2. Matriks internal eksternal

\section{HASIL DAN PEMBAHASAN}

\section{Jenis industri pengolahan ikan}

Industri pengolahan ikan di PPS Belawan terdiri dari berbagai jenis seperti pembekuan, pengeringan, peragian, dan pengasinan. Jumlah industri pengolahan ikan yang berada di PPS Belawan sebanyak 25 unit yang didominasi oleh industri pembekuan sebanyak 18 unit. Sebanyak 7 unit industri pengolahan ikan yang dijadikan sampel dalam penelitian ini (Tabel 2).

Jenis ikan yang diolah di industri pengolahan ikan yang ada di PPS Belawan adalah ikan pelagis dan ikan demersal. Dominannyaikan tersebutterkaitdenganalat tangkap yang digunakan di sekitar wilayah Selat Malaka (WPP 571) yaitu purse seine, boukeami, pancing, lampara dasar, dan pukat ikan. Berdasarkan data Kementerian Kelautan dan Perikanan, investasi industri pembekuan ikan mencapai US\$ 163,4 juta atau $68,1 \%$ dari pencapaian investasi sektor kelautan dan perikanan (Maulana 2017), ini menandakan industri pembekuan ikan sangat mendominasi dibanding industri pengolahan ikan lainnya.

\section{Estimasi kebutuhan industri pengolahan ikan}

Estimasi kebutuhan industri pengolahan ikan didapatkan dari ratarata kapasitas terpasang yang dijadikan sampel dikalikan dengan jumlah industri pengolahan ikan yaitu sebanyak 25 unit. Kapasitas terpasang industri pengolahan ikan di PPS Belawan dapat dilihat pada Tabel 3. 
Tabel 2. Jenis industri pengolahan ikan di PPS Belawan

\begin{tabular}{llcc}
\hline No & Industri Pengolahan Ikan & Jenis Industri & Jenis Ikan \\
\hline 1 & PT. Golden Cup Seafood & Pembekuan & Pelagis, demersal \\
2 & PT. Lautan Persada & Pembekuan & Pelagis \\
3 & CV. Selat Malaka Frozen & Pembekuan & Pelagis \\
4 & PT. Karya Agung & Pembekuan & Pelagis, demersal \\
5 & PT. Putri Indah & Pembekuan & Demersal \\
6 & Laut United & Pembekuan & Pelagis, demersal \\
7 & PT. Toba Surimi & Pembekuan & Pelagis, demersal \\
\hline
\end{tabular}

Tabel 3. Kapasitas terpasang industri pengolahan ikan

\begin{tabular}{llr}
\hline No & Industri Pengolahan Ikan & Kapasitas terpasang (ton) \\
\hline 1 & PT. Golden Cup Seafood & 3.300 \\
2 & PT. Lautan Persada & 3.000 \\
3 & CV. Selat Malaka Frozen & 1.200 \\
4 & PT. Karya Agung & 2.400 \\
5 & PT. Putri Indah & 3.600 \\
6 & Laut United & 4.500 \\
7 & PT. Toba Surimi & 6.000 \\
\hline \multicolumn{2}{l}{ Total } & 24.000 \\
\hline Rata-rata & 3.429 \\
\hline Estimasi kebutuhan industri $(\mathrm{N}=25)$ & 85.714 \\
\hline
\end{tabular}

Berdasarkan industri pengolahan ikan yang menjadi sampel, kebutuhan bahan baku industri dilihat dari kapasitas terpasang berkisar antara 1.200-6.000 ton. Kapasitas industri yang tertinggi yaitu 6.000 ton/tahun dan yang terendah yaitu 1.200 ton/tahun. Industri yang memiliki kapasitas terpasang yang tertinggi adalah PT. Toba Surimi, sementara yang terendah adalah CV. Selat Malaka Frozen. Kebutuhan bahan baku industri pengolahan ikan diestimasi dari rata-rata kapasitas terpasang industri pengolahan ikan yang dijadikan sampel dikali dengan jumlah total industri pengolahan ikan yang ada di PPS Belawan. Estimasi kebutuhan total industri pengolahan ikan yang ada di PPS Belawan sebesar 85.714 ton/tahun.

\section{Identifikasi asal ikan dan estimasi persediaan ikan di PPS Belawan}

Industri pengolahan ikan yang ada di PPS Belawan memperoleh bahan baku ikan dari dalam dan luar PPS Belawan. Daerah yang menjadi penyuplai terbesar bahan baku ke industri pengolahan ikan di PPS Belawan adalah Aceh, Batubara, Tanjung Balai, Padang, dan Sibolga. Menurut
Bakri (2014), Aceh adalah daerah terbesar penyuplai kebutuhan bahan baku industri pengolahan ikan yang ada di PPS Belawan. Sementara, ikan yang berasal dari dalam PPS Belawan disuplai dari kapal-kapal yang ada di PPS Belawan. Kapal-kapal ikan yang berada di PPS Belawan didominasi oleh kapal purse seine sebesar 51\% dari armada kapal yang ada di PPS Belawan.

Persediaan ikan diestimasi berdasarkan dari penjumlahan ikan yang tersedia di PPS Belawan dengan ikan yang dari luar masuk ke PPS Belawan. Persediaan ikan dari dalam PPS Belawan dapat dilihat pada Tabel 4.

Berdasarkan hasil penelitian jumlah persediaan ikan dari dalam pelabuhan sebesar 18.437 ton/tahun. Persediaan ikan tersebut didapatkan dari 241 unit kapal purse seine yang mendaratkan ikannya di dalam Pelabuhan. Namun jika dibandingkan dengan data statistik PPS Belawan total produksi ikan berbagai alat tangkap sebesar 28.709 ton/tahun. Sementara, persediaan ikan dari luar diperoleh berdasarkan dari pembagian kapasitas operasional dengan ikan yang dari PPS Belawan. Persediaan ikan dari luar PPS Belawan dapat dilihat pada Tabel 5. 
Tabel 4. Persediaan ikan dari dalam PPS Belawan

\begin{tabular}{llrr}
\hline No & \multicolumn{1}{c}{ Tangkahan } & Jumlah kapal (unit) & Total produksi (ton) \\
\hline 1 & Bincuan Nusantara & 4 & 297 \\
2 & BL & 2 & 153 \\
3 & Hoseng Chan & 5 & 369 \\
4 & Jaya Hasil Laut & 4 & 297 \\
5 & KAS & 3 & 243 \\
6 & Karya Laut & 6 & 450 \\
7 & LK & 6 & 459 \\
8 & Mustika Naga & 8 & 603 \\
9 & Sumber Bahari Utama & 9 & 720 \\
10 & TTS & 13 & 999 \\
\hline Total & 60 & 4.590 \\
\hline Rata-rata per kapal & $\mathrm{N}=241$ & 763,5 \\
\hline Estimasi persediaan ikan & & 18.437 \\
\hline
\end{tabular}

Tabel 5. Persediaan ikan dari luar PPS Belawan

\begin{tabular}{llrr}
\hline No & Industri Pengolahan Ikan & Kapasitas operasional (ton) & Ikan dari luar \\
\hline 1 & PT. Golden Cup Seafood & 2.400 & $60 \%$ \\
2 & PT. Lautan Persada & 1.200 & $90 \%$ \\
3 & CV. Selat Malaka Frozen & 840 & $70 \%$ \\
4 & PT. Karya Agung & 1.800 & $70 \%$ \\
5 & PT. Putri Indah & 3.000 & $15 \%$ \\
6 & Laut United & 2.400 & $60 \%$ \\
7 & PT. Toba Surimi & 3.600 & $50 \%$ \\
\hline \multicolumn{2}{l}{ Total } & 15.240 & $59 \%$ \\
\hline \multicolumn{2}{l}{ Tata-rata kapasitas operasional (N=25) } \\
\multicolumn{2}{l}{ Persediaan ikan dari luar (ton) } \\
\hline
\end{tabular}

Kebutuhan bahan baku untuk industri pengolahan ikan dipasok dari luar pelabuhan sebesar 32.268 ton. Data tersebut diperoleh dari 59\% dari kapasitas operasional (54.429 ton). Selain itu, kebutuhan bahan baku industri pengolahan ikan dipasok dari dalam pelabuhan sebesar 41\% yaitu 22.161 ton. Berdasarkan data statistik PPS Belawan tahun 2017, total produksi ikan berbagai alat tangkap sebesar 28.709 ton/ tahun sehingga terdapat sisa produksi yang tidak masuk ke industri pengolahan ikan sebesar 6.458 ton. Sisa tersebut di jual dalam bentuk segar ke pasar-pasar lokal. Alur pendistribusian ikan yang didaratkan di PPS Belawan dapat dilihat pada Gambar 3.

Berdasarkan hasil penjelasan di atas diketahui bahwa sebagian besar produksi ikan yang ada di PPS Belawan dipasok sebagai bahan baku industri pengolahan ikan dibandingkan dijual ke pasar-pasar lokal. Hal tersebut disebabkan ikan-ikan yang didaratkan di PPS Belawan merupakan ikan komoditi ekspor dan bernilai jual tinggi seperti ikan layur, kambing-kambing, ikan kakak tua, dan ikan kakap. Sesuai dengan hasil wawancara pihak industri pengolahan ikan yang ada di PPS Belawan bahwa ikanikan tersebut di ekspor ke China. Menurut Adrim (2008), Wahyuningsih et al. (2013), Tangko et al. (2002), ikan kakap, ikan kambing-kambing, dan ikan kakak tua merupakan ikan demersal yng bernilai ekonomis tinggi dan merupakan ikan ekspor di Indonesia.

Sebagian besar kebutuhan ikan yang masuk ke industri pengolahan ikan berasal dari luar PPS Belawan. Hal tersebut terjadi juga di tingkat nasional, sebanyak $60 \%$ bahan 
baku industri pengolahan ikan yang ada di Indonesia dipasok dari luar daerah. Bahkan untuk industri pengolahan ikan yang ada di PPS Belawan mendatangkan bahan baku ikan bukan hanya dari luar daerah saja tapi juga impor dari luar negeri seperti Malaysia dan Thailand. Rendahnya ketersediaan ikan di PPS Belawan dipengaruhi oleh beberapa faktor, antara lain berkurangnya armada penangkap ikan, terjadinya over fishing di wilayah penangkapan ikan, serta terbatasnya teknologi pengolahan hasil perikanan (Maulana 2017).

Informasi mengenai ketersediaan ikan dalam jangka waktu yang lama sangat penting bagi semua pihak, termasuk pedagang, industri pengolahan ikan dan pengelola pelabuhan (Hamzah et al. 2015). Ketersediaan bahan baku untuk industri pengolahan ikan sangat penting dalam pengembangan usaha industri pengolahan ikan. Bahan baku merupakan awal mula industri pengolahan ikan melakukan proses pengolahan. Supriyanto (2009) menyatakan estimasi bahan baku yang tersedia sangat diperlukan dalam perencanaan suatu usaha. Selain itu, ketersediaan sumberdaya ikan merupakan faktor penting dalam pengembangan dan perencanaan industri pengolahan ikan (Salampessy et al. 2012).

\section{Tingkat pemenuhan kebutuhan industri pengolahan ikan di PPS Belawan}

Tingkat pemenuhan kebutuhan industri pengolahan ikan merupakan hasil dari membandingkan antara kapasitas terpasang industri pengolahan ikan dengan kapasitas operasional industri pengolahan ikan. Berdasarkan hasil perhitungan antara kebutuhan industri pengolahan ikan (kapasitas terpasang) dengan persediaan ikan. Tingkat pemenuhan dari luar pelabuhan sebesar 38\% dan dalam pelabuhan sebesar $28 \%$ dengan total tingkat pemenuhan sebesar 63\% (Gambar 4). Hal ini sesuai dengan kondisi industri pengolahan ikan secara umum yang ada ditingkat nasional dimana tingkat pemenuhan industri pengolahan sebesar 50-60\% (Kemenperin 2016).

Persediaan ikan dari dalam dan luar pelabuhan dalam penelitian ini menunjukkan bahwa persediaan ikan di pelabuhan tidak mampu mencukupi kebutuhan bahan baku industri pengolahan ikan yang ada PPS Belawan. Apabila persediaan ikan tersebut tidak bisa mencukupi, maka akan berdampak ke operasional industri pengolahan ikan tersebut. Salah satu dampak terburuk yang bisa ditimbulkan dari bahan baku tidak tercukupi adalah industri tidak mampu beroperasi lagi. Kekurangan bahan baku membuat produksi industri pengolahan ikan berhenti beroperasi. Hal tersebut mengakibatkan dampak yang berantai, salah satunya mengurangi pendapatan pelabuhan. Hal ini seperti dinyatakan oleh Lubis et al. (2013), produksi ikan di pelabuhan perikanan sangat mempengaruhi pemenuhan kebutuhan bahan baku industri pengolahan ikan yang ada di suatu pelabuhan. Berikut alur tingkat pemenuhan kebutuhan dapat dilihat pada Gambar 5.

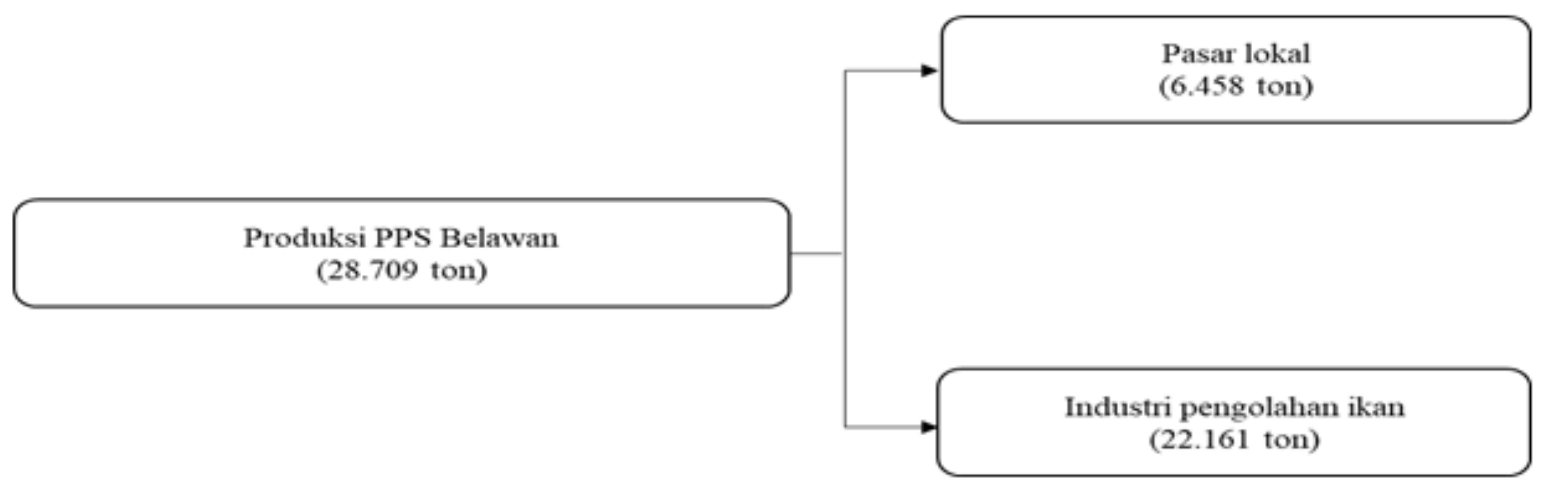

Gambar 3. Skema pendistribusian ikan yang didaratkan di PPS Belawan 


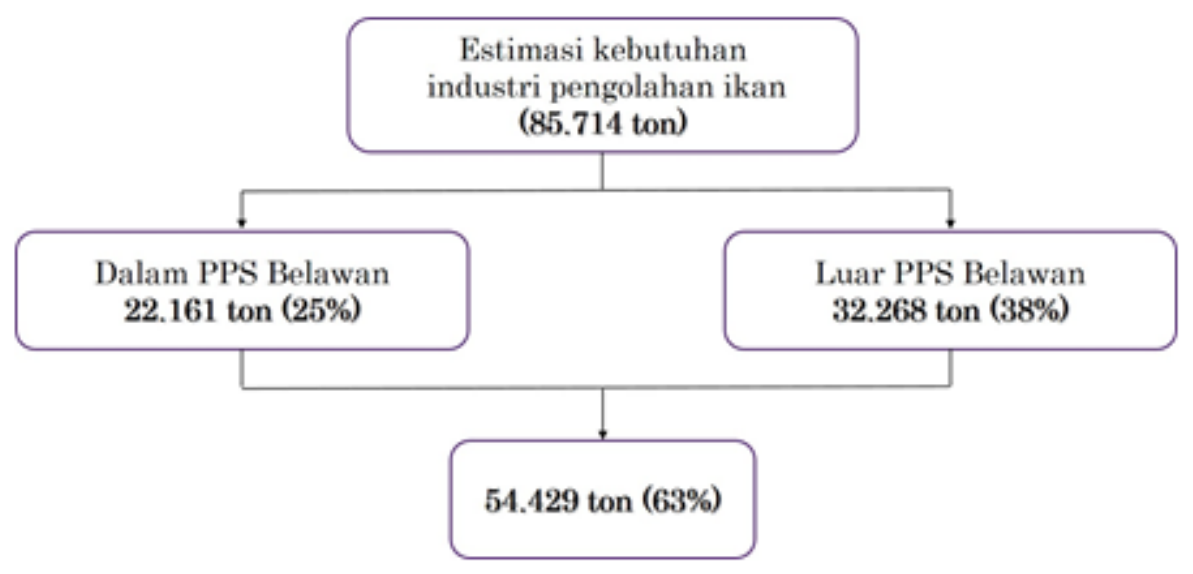

Gambar 4. Tingkat pemenuhan kebutuhan industri pengolahan ikan di PPS Belawan

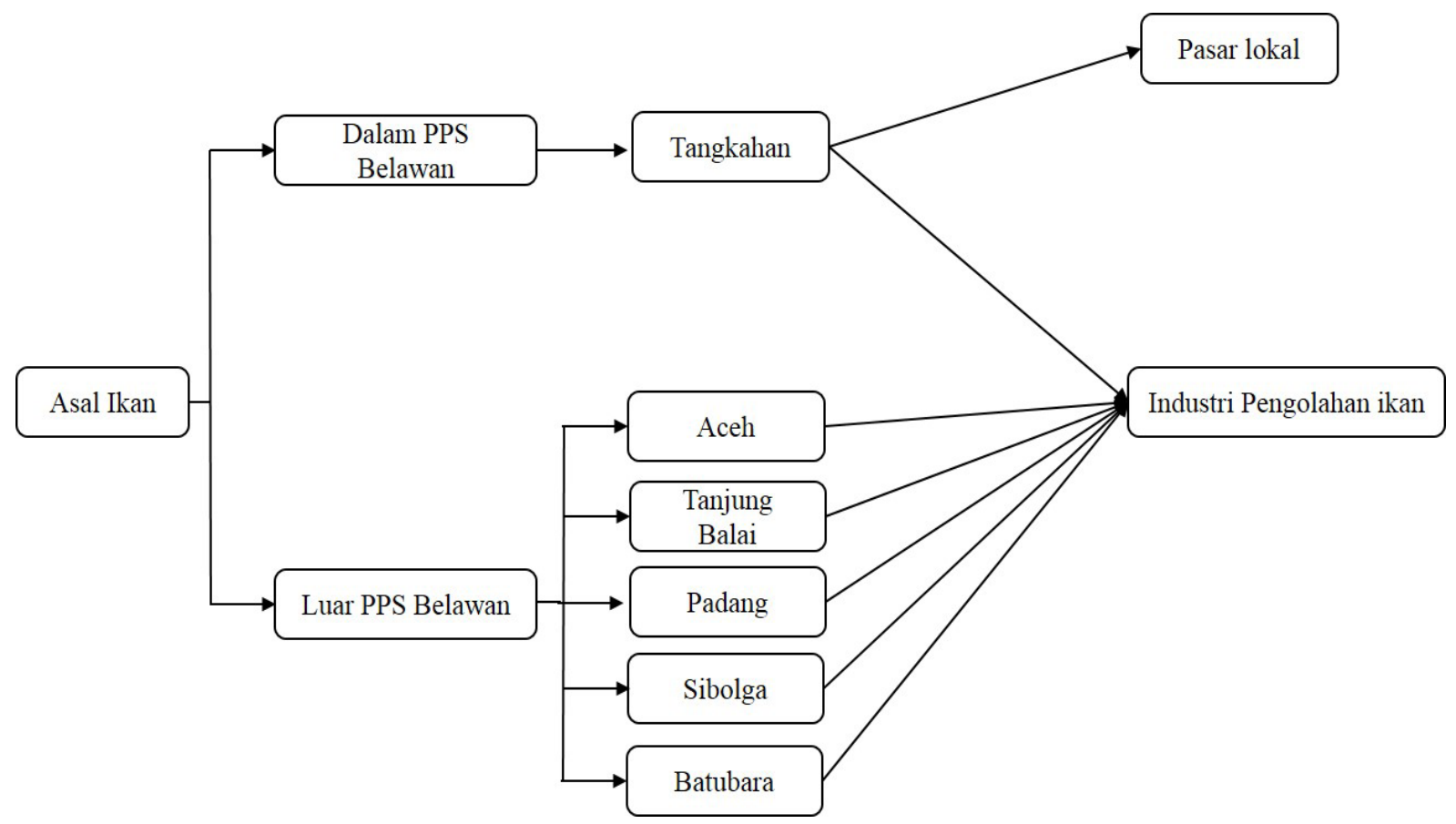

Gambar 5. Alur pemenuhan kebutuhan industri pengolahan di PPS Belawan

\section{Merumuskan strategi pemenuhan kebutuhan industri pengolahan ikan}

\section{Analisis matriks Internal Factor Analysis} Summary (IFAS)

Matriks IFAS digunakan untuk menganalisis faktor-faktor internal yaitu faktor-faktor yang menjadi kekuatan dan kelemahan untuk penyusunan strategi pemenuhan bahan baku industri pengolahan ikan di PPS Belawan (Tabel 6). Nilai bobot merupakan urgensi penanganan dalam pemenuhan kebutuhan. Nilai bobot diberi dengan skala 1 (sangat penting) sampai dengan 0 (tidak penting), sementara nilai rating adalah kondisi saat ini yang terjadi di PPS Belawan. Nilai rating untuk masing-masing faktor diberikan dengan skala 4 (sangat kuat) sampai dengan 1 (sangat lemah). Pemberian rating untuk faktor yang tergolong kategori kekuatan bersifat positif (kekuatan yang besar diberi rating 4, sedangkan jika kekuatannya kecil diberi rating 1). Pemberian rating kelemahan adalah kebalikannya, yaitu jika kelemahannya sangat besar diberi rating 1 dan jika kelemahannya kecil ratingnya 4. Berdasarkan Tabel 6 nilai IFAS yang didapatkan adalah 2,63. Nilai tersebut mengindikasikan posisi internal yang kuat karena nilai total skor $>2,5$ (David 2006 dalam Tyas dan Chriswahyudi 2017). Hal itu menandakan bahwa PPS Belawan memiliki 
kekuatan yang lebih besar dibandingkan dengan kelemahan untuk dapat memenuhi kebutuhan bahan baku industri pengolahan ikan yang ada.

\section{Analisis matriks External Factor Analysis Summary (EFAS)}

Matriks EFAS digunakan untuk menganalisis faktor-faktor eksternal yaitu faktor-faktor yang menjadi peluang dan ancaman dalam pembuatan strategi. Hasil identifikasi peluang dan ancaman dimasukkan sebagai faktor eksternal, yang kemudian diberi bobot dan rating sehingga diperoleh nilai (skor) seperti Tabel 7. Nilai bobot merupakan urgensi penanganan dalam pemenuhan kebutuhan. Nilai bobot diberi dengan skala 1 (sangat penting) sampai dengan 0 (tidak penting), sementara nilai rating adalah kondisi saat ini yang terjadi di PPS Belawan. Nilai rating untuk masing-masing faktor diberikan dengan skala 4 (sangat kuat) sampai dengan 1 (sangat lemah). Pemberian rating untuk faktor yang tergolong kategori peluang bersifat positif (peluang yang besar di beri rating 4, sedangkan jika peluangnya kecil diberi rating 1). Pemberian rating ancaman adalah kebalikannya, yaitu jika ancamannya sangat besar diberi rating 1 dan jika ancamannya kecil ratingnya 4.

Total bobot matriks EFAS yang didapat adalah 2,89. Total skor tersebut dalam strategi ini tergolong cukup kuat. Hal tersebut menandakan bahwa kegiatan pemenuhan kebutuhan industri pengolahan ikan merespon baik peluang dan ancaman yang ada. Menurut David (2009) dalam Muchransyah et al. (2018) skor pembobotan di atas 2,5 tergolong kuat dan di bawah 2,5 tergolong lemah.

\section{Strategi SWOT}

Matriks internal eksternal dalam pemenuhan kebutuhan industri pengolahan ikan penting untuk mensinkronkan strategi-strategi yang tepat sesuai dengan keadaan sekarang. Nilai total bobot IFAS sebesar 2,75 dan total skor EFAS sebesar 2 ,84. Hal tersebut menunjukkan bahwa nilai IFAS dan EFAS berada pada posisi kuadran V. Kuadran V menunjukkan bahwa pemenuhan kebutuhan industri pengolahan ikan di PPS Belawan dalam kondisi pertumbuhan dengan konsentrasi pada integrasi horizontal atau stabilitas (Tarigan et al. 2018). Posisi matriks internal eksternal dapat dilihat pada Gambar 6.

Tabel 6. Matriks IFAS

\begin{tabular}{|c|c|c|c|c|}
\hline No & Kekuatan & Bobot & Rating & Skor \\
\hline 1 & $\begin{array}{l}\text { PPS Belawan pelabuhan terbesar di Sumut sehingga } \\
\text { menunjang bahan baku banyak di distribusikan ke PPS } \\
\text { Belawan }\end{array}$ & 0,12 & 4 & 0,45 \\
\hline 2 & Industri pengolahan ikan di PPS Belawan berskala besar & 0,11 & 3 & 0,34 \\
\hline 3 & $\begin{array}{l}\text { Fasilitas pelabuhan mendukung untuk kegiatan industri } \\
\text { pengolahan ikan }\end{array}$ & 0,11 & 4 & 0,37 \\
\hline 4 & $\begin{array}{l}\text { SDM di industri pengolahan ikan dalam jumlah dan } \\
\text { kapasitas yang memadai }\end{array}$ & 0,11 & 3 & 0,33 \\
\hline 5 & $\begin{array}{l}\text { SDM nelayan dalam jumlah dan kapasitas yang mema- } \\
\text { dai }\end{array}$ & 0,11 & 3 & 0,37 \\
\hline No & $\begin{array}{l}\text { Kelemahan } \\
\end{array}$ & Bobot & Rating & Skor \\
\hline 1 & Penurunan produksi bahan baku ikan & 0,12 & 2 & 0,21 \\
\hline 2 & $\begin{array}{l}\text { Penurunan armada penangkapan ikan dalam } 5 \text { tahun } \\
\text { terakhir }\end{array}$ & 0,11 & 2 & 0,18 \\
\hline 3 & $\begin{array}{l}\text { Industri pengolahan ikan di PPS Belawan masih bergan- } \\
\text { tung masih bahan baku dari luar }\end{array}$ & 0,13 & 2 & 0,19 \\
\hline 4 & Kapasitas industri pengolahan ikan belum optimal & 0,10 & 2 & 0,18 \\
\hline \multicolumn{2}{|c|}{ Total } & 1 & & 2,63 \\
\hline
\end{tabular}


Tabel 7. Matriks EFAS

\begin{tabular}{llrrc}
\hline No & \multicolumn{1}{c}{ Peluang } & Bobot & Rating & Skor \\
\hline 1 & Pangsa pasar domestik dan ekspor & 0,14 & 3 & 0,46 \\
2 & Tingginya nilai jual komoditas ikan olahan & 0,12 & 3 & 0,40 \\
3 & Aksebilitas lokasi yang baik & 0,12 & 4 & 0,46 \\
4 & Tingginya permintaan pasar terhadap ikan olahan & 0,12 & 4 & 0,45 \\
5 & Lokasi pelabuhan yang strategis & 0,13 & 4 & 0,49 \\
\hline No & \multicolumn{1}{c}{ Ancaman } & Bobot & Rating & Skor \\
\hline 1 & Konflik antar nelayan & 0,12 & 2 & 0,22 \\
2 & Peraturan pemerintah tentang pelarangan alat tangkap & 0,13 & 2 & 0,20 \\
3 & trawl & 0,12 & 2 & 0,23 \\
\hline Total & 1 & & 2,89 \\
\hline
\end{tabular}

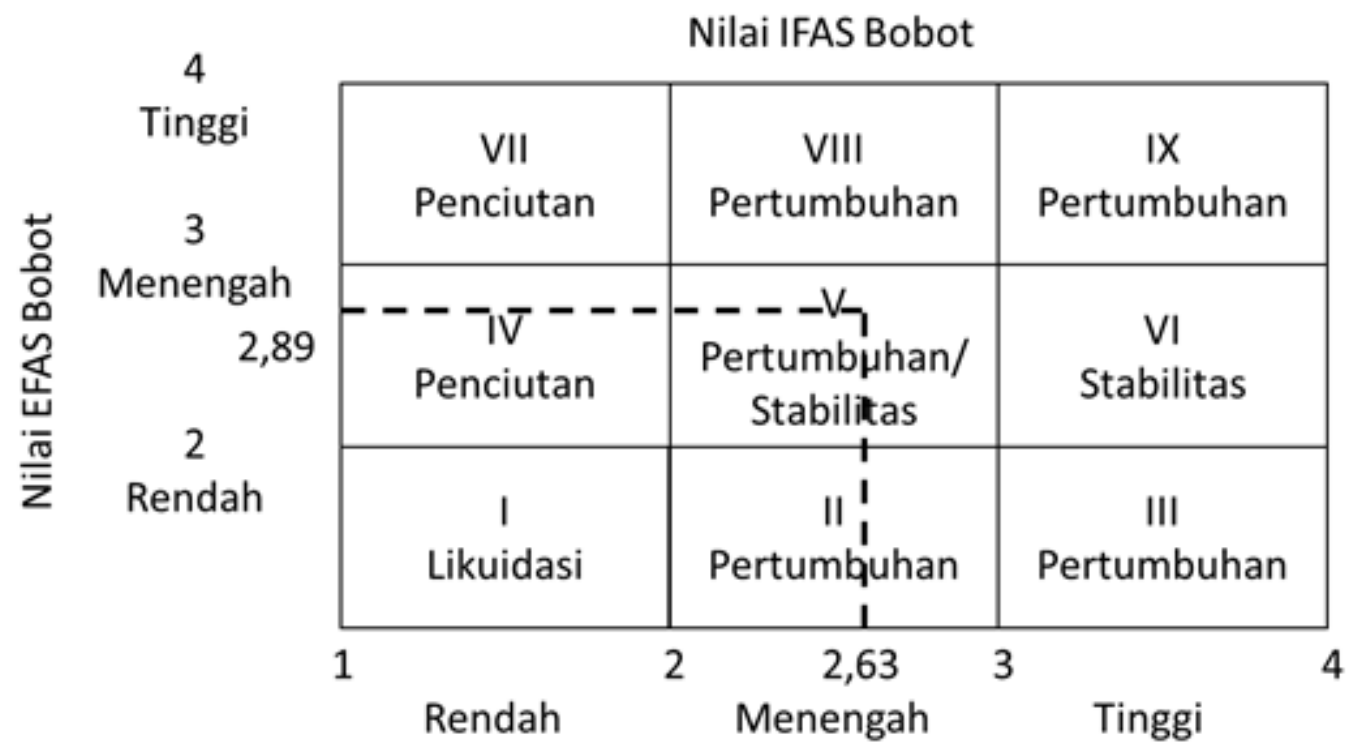

Gambar 6. Matriks internal eksternal posisi pelaksanaan pemenuhan kebutuhan industri pengolahan ikan di PPS Belawan

Berdasarkan hasil dari matriks SWOT di atas diperoleh 4 alternatif strategi yang dapat dilakukan PPS Belawan untuk memenuhi kebutuhan bahan baku industri pengolahan. Adapun 4 alternatif tersebut adalah sebagai berikut:

1. Strategi S-O: Melakukan pengembangan fasilitas (cold storage) serta pemanfaatan SDM untuk memenuhi kebutuhan indutri pengolahan. Pengembangan infrastruktur atau fasilitas di pelabuhan dapat memberikan pengaruh terhadap akses ke sumberdaya sehingga dapat meningkatkan produksi sumberdaya tersebut (Putra dan Djalante 2016). Menurut Kemenperin (2018), ketersediaan bahan baku dapat menjaga kontinuitas produksi industri guna memenuhi kebutuhan pasar domestik dan ekspor,
2. Strategi S-T: Melakukan kerjasama dengan pihak luar dalam dalam menunjang ketersediaan dan harga bahan baku yang terus stabil. Dalam menunjang kebutuhan bahan baku, PPS Belawan dapat melakukan kerjasama dengan pihak luar seperti dengan daerah lain yang memiliki jenis ikan yang dibutuhkan industri pengolahan ikan. Selain itu PPS Belawan bisa melakukan konektivitas antar pelabuhan dalam distribusi produksi perikanan. Konektivitas antar pelabuhan perikanan dapat membantu memenuhi kebutuhan industri pengolahan ikan (Solihin et al. 2012).

3. Strategi W-O: Menambah jumlah armada penangkapan ikan dan mendorong armada melakukan penangkapan ikan yang menjadi kebutuhan industri 
pengolahan. Armada penangkapan ikan yang ada di PPS Belawan dominan menagkap ikan pelagis dan demersal karena alat tangkap yang banyak digunakan yaitu purse seine, boukeami, dan pukat ikan. Menurut Tawari et al. (2014) jumlah armada yang optimum dapat digunakan untuk memanfaatkan potensi sumberdaya yang ada ikan di suatu perairan.

4. Strategi W-T: Melakukan penegakan hukum terhadap kegiatan yang menghambat akses bahan baku masuk ke industri pengolahan ikan. Menurut Sudarman (2018) pungutan liar merupakan ancaman bagi pengusaha, sehingga para pengusaha menekan biaya operasional. Akibatnya para pengusaha enggan memasok bahan baku ke daerah yang banyak terjadi pengutan liar.

\section{KESIMPULAN DAN SARAN}

\section{Kesimpulan}

1. Estimasi kebutuhan kapasitas terpasang industri pengolahan ikan yang ada di PPS Belawan sebesar 85.714 ton/tahun.

2. Persediaan total ikan yang masuk ke industri pengolahan ikan sebesar 54.429 ton serta tingkat pemenuhannya dari luar pelabuhan $38 \%$ dan dalam pelabuhan $26 \%$.

3. Strategi dalam pemenuhan bahan baku tersebut adalah melakukan pengembangan fasilitas (cold storage dan aksesibilitas tansportasi) serta pemanfaatan SDM untuk memenuhi kebutuhan indutri pengolahan, melakukan kerjasama dengan pihak luar dalam dalam menunjang ketersediaan dan harga bahan baku yang terus stabil, mendorong armada melakukan penangkapan ikan yang menjadi kebutuhan industri pengolahan ikan, dan melakukan penegakan hokum terhadap yang menghambat akses bahan baku masuk ke industri.

\section{Saran}

Merekomendasikan strategi yang telah dibuat kepada PPS Belawan untuk memenuhi kebutuhan industri pengolahan ikan yang ada disana.

\section{DAFTAR PUSTAKA}

Adrim M. 2008. Aspek Biologi Ikan Kakatua (Suku Scaridae). Oseana. 33(2): 4150.

Bakri. 2014. Aceh Pasok 80\% Kebutuhan Pabrik Ikan di Medan. https:// aceh.tribunnews.com. [15 Desember 2019].

[FAO] Food and Agriculture Organization. 2017. Handbook for Fisheries SocioEconomic Sample Survey. Rome (ID): FAO.

Hamzah A, Pane AB, Lubis E, Solihin I. 2015. Potensi Ikan Unggulan sebagai Bahan Baku Industri Pengolahan di PPN Karangantu. Marine Fisheries. 6(1): 45-58.

Kemenperin. 2016. Kemenperin Targetkan Utilisasi Industri Pengolahan Ikan Naik 90 Persen. https://kemenperin. go.id/. [15 Desember 2019].

Kemenperin. 2018. Jaminan Bahan Baku Industri Tingkatkan Ekspansi daan Investasi. https://kemenperin. go.id/. [15 Desember 2019].

[KKP] Kementerian Kelautan dan Perikanan. 2012. Peraturan Menteri Kelautan dan Perikanan nomor 8 tahun 2012 Tentang Kepelabuhanan Perikanan. Jakarta (ID): KKP. http://jdih.kkp. go.id. [15 Desember 2019].

Lubis E, Nugroho T, Witry SDB. 2013. Produksi Hasil Tangkapan sebagai Bahan Baku Industri Pengolahan: Kasus Pelabuhan Perikanan Pantai Muncar Kabupaten Banyuwangi. Buletin PSP. 21(1): 77-95.

Maulana R. 2017. Utilitas Pabrik Pengolahan ikan di Sulut Menuju Titik Nadir. https://ekonomi.bisnis.com/read. [14 Desember 2019].

Muchransyah MHQ, Sarma M, Najib M. 2018. Analisis Internal dan Eksternal Kentang Indoneisa dalam Menghadapi Masyarakat Ekonomi ASEAN (MEA). Jurnal Manajemen dan Organisasi. 9(2): 115-121.

Nurul A. 2015. Daftar Unit Pengolahan Ikan Skala Besar. https://id.scribd.com/ doc/270603149/Daftar-UPI-SkalaBesar-2013-NEW. [15 Mei 2019].

[PPSB] Pelabuhan Perikanan Samudra Belawan (ID). 2017. Buku Statistik PPSB. Direktorat Jendral Kementrian Kelautan Perikanan (KKP). 1(1): 50- 
65.

Purwaningsih R, Partiwi SR. 2014. Analisa Pengaruh Penurunan Stok Ikan Lemuru terhadap Keberlanjutan Industri Pengolahan Ikan Muncar Banyuwangi dengan Model Sistem Dinamik. Seminar Nasional IDEC 2014. 2-9.

Putra AA, Djalante. 2016. Pengembangan Infrastruktur Pelabuhan dalam mendukung Pembangunan Berkelanjutan. Jurnal Ilmiah Media Engineering. 6(1): 433-443.

Rangkuti F. 2006. Analisis SWOT Teknik Membedah Kasus Bisnis. Jakarta: PT. Gramedia Pustaka Utama.

Salampessy RBS, Permadi A, Haluan J. 2012. Kajian Analisis Pengembangan Pengolahan Hasil Perikanan di Kabupaten Serang. Jurnal Ilmu Pertanian dan Perikanan. 1(1): 9-16.

Siahaan FTS, Mudzakir AK, Dewi DANN. 2016. Tingkat Pemanfaatan Fasilitas Dasar dan Fungsional di Pelabuhan Perikanan Samudera Belawan dalam Menunjang Kegiatan Penangkapan Ikan. Journal of Fisheries Utilization Management and Technology. 2(5): 55-63.

Solihin I, Wisudo SH, Susanto J. 2012. Sistem Konektivitas Pelabuhan Perikanan untuk Menjamin Ketersediaan Bahan Baku Bagi Industri Pengolahan ikan. Prosiding Seminar Nasional Ikan ke 8.

Sudarman. 2018. Penegakan Hukum terhadap Pungutan Liar pada Pengujian Kendaraan Bermotor (PKB) di Dinas Perhubungan Kabupaten Agam oleh Satuan Tugas Sapu Bersih Pungutan liar. ISSN. 1(2): 211-221.

Supriyanto. 2009. Business Plan sebagai Langkah Awal Memulai Usaha. Jurnal Ekonomi dan Pendidikan. 6(1): 73-83.

Tangko AM, Mansyur A, Pongsapan D. 2002. Pengaruh Penggunaan Gelembung Udata sebagai Alat Bantu Jaring Lingkar Bubu terhadap Hasil Tangkapan Ikan Hias. JPPI. 8(4): 6572.

Tarigan JD, Simbolon D, Wiryawan B. 2018. Strategi Pengelolaan Perikanan Gurita di Kabupaten Banggai Laut, Provinsi Sulawesi Tengah. JTPK. 9(1): 13-24.

Tawari RHS, Simbolon D, Purbayanto A, Taurusman AA. 2014. Analisis Optimasi Armada Penangkapan Madidihang Skala Kecil di Kabupaten Seram Bagian Barat. Marine Fisheries. 5(2): 129-137.

Tyas SK, Chriswahyudi. 2017. Perencanaan Strategi Pemasaran dengan Pendekatan Matrik IE, SWOT dan AHP untuk Mendapatkan Alternatif Strategi Prioritas. Disampaikan pada Seminar Nasional Sains dan Teknologi. Tanggal 1-2 November 2017.

Wahyuningsih, Prihatiningsih, Ernawati T. 2013. Parameter Populasi Ikan Kakap Merah (Lutjanus malabaricus) di Perairaan Laut Jawa Bagian Timur. Bawal. 5(1): 175-179. 